\title{
California set to get tough
}

\section{San Francisco}

REGULAR reviews of the performance of all tenured professors and a mandatory 'rehabilitation' programme for those found wanting are likely to be adopted by the University of California (UC).

The new measures, a compromise after a more radical proposal was defeated in a vote last year, will signal the end of protection of incompetent faculty members within the nine-campus UC system and will almost certainly lead to changes at other universities.

In May 1986, the University Committee on Academic Personnel (UCAP) urged each campus to adopt a policy of mandatory review for all professors at least every five years. The University of California at present has an eight-step pay scale for tenured full professors, with no mandatory reviews after the fifth level is reached.

The Berkeley campus adopted mandatory review the following September and then went a step further, examining what could be done when the review shows inadequacy in both teaching and research. Pressure from legislators, who believe that money could be saved if ageing senior faculty were replaced with more junior members, was one factor stimulating action. Another was the 1986 amendment to the Age Discrimination in Employment Act which by 1994 will eliminate mandatory retirement for university faculty and could allow faculty to stay at work well into their dotage.

By 1988 , Berkeley had come up with a set of recommendations which suggested that when both teaching and scholarship standards became dismal, appointments should be terminated. But automatic dismissal was judged too severe when presented to other UC campuses, and last June a university committee was set up to work out measures acceptable to all. Its conclusions are now becoming clear, although it is not expected to deliver a preliminary report until the end of the academic year.

The committee chairman, chemistry professor Charles Nash of UC Davis, says that the Berkeley proposal read like a "search and destroy mission". He favours instead regular reviews for all faculty. In the course of these evaluations, he said, "there might be identified an occasional individual for whom additional inquiry might be appropriate". Nash said the new plan will probably enhance standing rules that suggest rehabilitative procedures for failing faculty. "My gut feeling . . . would be simply to mandate rehabilitative efforts as a first step", said Nash. The existing policy of terminating a faculty member only if rehabilitative efforts fail would not change.

Favouring the more low-key approach is the American Association of University Professors, which feels that most universities already have adequate safeguards against faculty incompetence. "It's almost standard for a university to include a lack of competence as one of three general categories that are grounds for dismissal", said Jordan Kurland, its associate general secretary. The others are misconduct and neglect of duties.

One problem is that despite their rules, few schools have ever done anything about incompetent faculty members. And any step by the University of California system toward changing that situation is likely to affect the approximately 5,000 four-year institutions in the United States and their 200,000 tenured faculty members, said Kurland. "The University of California is basically an enlightened system, a terribly influential system, and whatever they do is important", he says.

Nash agreed, citing a new era for universities. "The idea that the demonstrably incompetent tenured faculty member is protected, that's what is dead", he said.

Robert Buderi

\section{Discrimination case victory}

\section{Washington}

US universities will have to reappraise the need for confidentiality in tenure review following a Supreme Court ruling that federal investigators can force universities to show them confidential tenure evaluations. The court decided in favour of the Federal Equal Employment Opportunity Commission (EEOC) and Rosalie Tung, a former management professor at the University of Pennsylvania. Tung, a ChineseAmerican, had complained that she had been unfairly denied tenure because of her sex, race and national origin.

The court rejected the university's argument that removing a guarantee of anonymity would discourage "candor" in tenure decisions. "Not all academics will hesitate to stand up and be counted when they evaluate their peers", Justice Harry Blackmon said in a written opinion.

The case is seen as critical by many US universities. "Our concern is that eliminating confidentiality will drive the tenure process underground", says David Merkowitz, director of public affairs for the American Council on Education. He believes that the knowledge that a reviewer's name can be handed over to federal investigators, and aggrieved tenure candidates, could have a "chilling effect" on the review process. Rather than submitting written and signed opinions, peer reviewers may be willing only to discuss the issue in private. And then, Merkowitz says, the "old boy network will be making the decision". The immediate reaction in the academic community seems to be a cautious wait-and-see. At the University of Pennsylvania, general counsel Shelley Green says that no immediate changes to the tenure process are planned. "If we find that there are problems in getting recommendation letters [from peer reviewers], we'll have to reappraise our policies", she says.

One likely compromise, at least for the immediate future, is for universities to hand over review documents but to withhold the names of the reviewers. That method is already practised by the National Science Foundation and the Department of Health and Human Services (HHS) in their grant-approval process, as well as by many scientific journals in reviewing manuscripts submitted for publication. In two separate cases last year, HHS's Centers for Disease Control and the journal Physical Review Letters both survived lawsuits that sought to reveal the names and comments of peerreviewers. And at the National Institutes of Health, individual comments are destroyed after they are summarized, effectively ruling out a subpoena.

But the tenure process may not be so resistant to lawsuits. "The courts have to balance the need for academic freedom with Congress's dictate of non-discrimination in employment", says Allan Ryan of Harvard University's general counsel's office. And he suggests that the will of Congress may often take priority.

Although Harvard recently won a decision which allowed it to obscure reviewers' names in a tenure decision, that case is under appeal.

Future suits are likely to be settled on a case-by-case basis, says Thomas Wright, general counsel for Princeton University. If the investigators can convince a judge that the selection of reviewers may have been inappropriate, the university could be forced to reveal their names, he says. Nevertheless, until some legal precedent is set, Princeton and several other prominent universities have said that they intend to turn over peer-review documents without the names of the reviewers and fight the court battles when they come.

G. Christopher Anderson

\section{Tunnel still news}

EUROTUNNEL, the company managing the present attempt to link England and France, last week secured finance to keep the Channel tunnel alive. Was the optimism displayed by Nature 120 years ago justified? See Then and Now, facing the inside back cover. 